\title{
Studies on Proteolytic Enzymes of Streptomyces griseus
}

\author{
Part I. Separation and Purification of Peptidase and Proteinase \\ from Culture Media of Streptomyces griseus ATCC 3463*
}

\author{
By Takeshi Ouchi \\ Department of Agricultural Chemistry, Faculty of Agriculture, \\ Ibaraki University, Ami, Ibaraki \\ Received December 25, 1961
}

\begin{abstract}
Separation and purification of proteolytic enzymes of Streptomyces griseus ATCC 3463 were undertaken by fractional precipitation with ethanol and ammonium sulfate followed by dialysis and finally applying zone electrophoresis on starch. In the experiment, peptidase free from proteinase and the latter enzyme free from the former were obtained. The purity was increased approximately 90 -fold with the peptidase and 8 -fold with the proteinase.
\end{abstract}

Nomoto and his coworkers ${ }^{1,2)}$ demonstrated the presence of a neutral protease in the culture filtrate of a strain of Streptomyces griseus. The enzyme digested various substrates for both endopeptidase and exopeptidase.

Tytell $^{3)}$ has also purified a neutral proteinase, which acts on substrates commonly used for pepsin assay, from the culture media of a strain of Streptomyces proteolyticus. Up to date, few literatures have been published on peptidase of Streptomyces species. The present author has found that Streptomyces griseus ATCC 3463 showed the most potent peptidase- and proteinase activity among eight strains of Streptomyces species tested. In order to know more about the proteolytic enzymes of the strain, the proteolytic enzyme of the culture filtrate was purified and the above two enzyme activities were found to be ascribed to the two enzymes, proteinase and

\footnotetext{
* A part of this report was presented at the annual meeting of the Agricultural Chemical Society of Japan, Tokyo, April 6, 1960.

1) M. Nomoto and Y. Narahashi, J. Biochem., 46, 839 (1959).

2) M. Nomoto and Y. Narahashi, ibid., 46, 1481 (1959).

3) A.A. Tytell, J. Charney, W.A. Bolhofer and C. Curran, Fed. Poc., 13, 312 (1954).
}

peptidase, respectively. The present study deals with the method of separation of the proteinase and the peptidase and of purification of the two enzymes to make possible further study of their specificities. Studies of enzymatic properties of them will be presented elsewhere.

\section{EXPERIMENTAL}

\section{Cultural Condition.}

Streptomyces griseus ATCC 3463 was grown in Buillon medium containing one per cent glucose ( $\mathrm{pH}$ 7.0) for three days at $27^{\circ} \mathrm{C}$ on a shaker. The culture filtrate was used as a crude enzyme solution.

\section{Fractional Precipitation with Alcohol.}

The culture filtrate was found to hydrolyze several kinds of substrates that are used for peptidase and proteinase activity assay. With the purpose of separating peptidase and proteinase from each other, the procedure of fractional precipitation with ethanol and ammonium sulfate was applied to the culture filtrate, and the enzymes were finally purified by zone electrophoresis on starch. The culture filtrate was chilled below $0^{\circ} \mathrm{C}$ and equal volume of cold ethanol was added. After standing of ten minutes, the precipitate occurred was removed by centrifugation and 
the supernatant liquid was again chilled below $0^{\circ} \mathrm{C}$. The ethanol concentration was then raised up to 66 per cent and after centrifugation, it was further increased to 80 per cent by the addition of cold ethanol. The precipitates at each ethanol concentration were collected by centrifugation and washed with cold ethanol and dried in vacuo. The precipitate obtained between zero and 50 per cent ethanol concentration showed a negligibly slight activity of peptidase and proteinase. The most active proteinase activity was found in the fraction obtained between 50 and 66 per cent ethanol concentration. On the other hand, the precipitate that occurred between 66 and 80 per cent ethanol concentration was remarkable in its peptidase activity. The two fractions were subjected to further purification.

\section{Purification of Peptidase.}

Two grams of the dried powder was extracted twice with $15 \mathrm{ml}$ portions of water at room temperature and then the solution was centrifuged (3000 r.p.m., fifteen min.). To the supernatant solution $(30 \mathrm{ml})$ was added solid ammonium sulfate to 0.4 saturation at $\mathrm{pH} 7.0$ and $0^{\circ} \mathrm{C}$, and after one hour standing the precipitate formed was removed by centrifugation (12000 r.p.m., fifteen min.). An additional solid ammonium sulfate was added to make 0.8 saturation at $\mathrm{pH} 7.0$ and then the solution was left to stand for one hour followed by centrifugation as before. The precipitate was collected, dissolved in $10 \mathrm{ml}$ of water, and dialyzed against water at $\mathrm{pH} 8.0$ below $2{ }^{\circ} \mathrm{C}$. To the dialysate was again added solid ammonium sulfate to 0.5 saturation at $\mathrm{pH} 7.0$, then the solution was allowed to stand in the cold for one hour and centrifuged (12000 r.p.m., fifteen min.). To the supernatant solution, further solid ammonium sulfate was added to make 0.7 saturation at $\mathrm{pH} 7.0$ and after standing of one hour the solution was centrifuged as before. The precipitate thus obtained was collected, dissolved in $2 \mathrm{ml}$ of cold water, and dialyzed against water changed every one hour at pH 8.0 below $2^{\circ} \mathrm{C}$.

The dialyzed solution was then transferred into a short test tube and heated at $60^{\circ} \mathrm{C}$ for twenty minutes in order to remove contaminated other proteolytic enzymes. Then the solution was quickly chilled in an ice water bath at $0^{\circ} \mathrm{C}$, and centrifuged to remove the precipitate formed by heating.

The final step in the purification was performed by use of a zone electrophoresis apparatus (Model 2 of Tōyō Roshi Co., Ltd., Japan) in a cold room at around $3^{\circ} \mathrm{C}$. After electrophoresis the enzyme was eluted from the starch columns cut into 1-cm-length.

\section{Purification of Proteinase.*}

The purification of the proteinase was carried out by a method similar to that applied to the peptidase. The dried powder obtained between 50 and 66 per cent ethanol concentration was extracted twice with water at room temperature and a clear solution was obtained by filtration. To the solution was added solid ammonium sulfate and the precipitate obtained between 0.3 and 0.5 saturation of the salt was collected, dialyzed and subjected to the electrophoresis.

\section{Preparation of Substrate.}

DL-Leucylglycine** was synthesized according to the Fischer's method ${ }^{4)}$. Glycylglycine, glycylglycyl-L-leucine were synthesized by the phthalyl method ${ }^{5)}$. DLLeucylglycylglycine was synthesized by means of both the above methods. L-Leucine amide was prepared after Smith's method $^{(8)}$. Casein was prepared from fresh milk according to the usual method ${ }^{7}$.

\section{Determination of Peptidase Activity.}

Peptidase activity was assayed by the alcohol titration method of Grassmann and Heyde as reported previously ${ }^{8,9)}$. Unless otherwise noted, the condition of digestion was as follows: $0.05 \mathrm{M}$ tris $\mathrm{pH} 8.0 ; 0.10 \mathrm{M}$ Leu-Gly-Gly; total volume of digestion mixture, one $\mathrm{ml}$; digestion period, one hour at $40^{\circ} \mathrm{C}$. Hydrolysis is expressed as 100 per cent for complete splitting of one peptide bond. Activity is expressed as the zero order constant $k_{0}$. Specific activity $\mathrm{C}_{0}$ was defined as $\mathrm{C}_{0}=\mathrm{k}_{0} / \mathrm{E}$, where $\mathrm{E}$ is the enzyme protein $\mathrm{N}$ in $\mathrm{mg}$ per $\mathrm{ml}$ of the reaction mixture. The total activity in units was calculated from the $\mathrm{C}_{0}$ value being multiplied by number of $\mathrm{mg}$ of protein $\mathrm{N}$ contained

\footnotetext{
* Another method for purification of the enzyme is now being studied using Duolitc C-10 ion exchanger column.

** The following abbreviations are used: Gly-Gly, glycylglycine ; Gly-Gly-Leu, glycylglycyl-L-leucine ; Leu-Gly, DL-leucylglycine ; Leu-GlyGly, DL-leucylglycylglycine; Leu- $\mathrm{NH}_{2}$, L-leucine amide; tris, tris (hydroxymethyl) aminomethane; TCA, trichloroacetic acid.

4) E. Fischer, "Untersuchungen über Aminosäuren, Polypeptide und Proteine ", Verlag von Julius Springer, Berlin, I (1906), II (1919).

5) J.C. Sheehan and V.S. Frank, J. Am. Chem. Soc., 71, 1856 (1946).

6) E.L. Smith and N.B. Slonim, J. Biol. Chem., 176, 835 (1948).

7) E.J. Cohn and J.L. Hendry, "Organic Syntheses", (in Japanese), Maruzen, 1951, p. 157.

8) W. Grassmann und W. Heyde, Z. Physiol. Chem., 183, 32 (1929). 9) M. Sato, T. Ouchi, A. Hiramatsu and T. Akatsuka, Ibaraki Da:gaku Nōgakubu Gakujutsu Hōkoku, 4, 59 (1956); M. Sato and T. Akatsuka, This Journal, 23, 465 (1959).
} 
in enzyme solution.

\section{Determination of Proteinase Activity.}

Proteolytic activity was measured according to the method of Anson 10,11). The incubation system consisted of one $\mathrm{ml}$ of 0.6 per cent casein in $0.05 \mathrm{~N}$ $\mathrm{NH}_{4} \mathrm{OH}-\mathrm{NH}_{4} \mathrm{Cl}$ buffer ( $\mathrm{pH} 10.0$ ), and $0.2 \mathrm{ml}$ of enzyme solution, and the mixture was placed in a small test tube with two limbs. The substrate solution was pipetted into one of the limbs and the enzyme solution into the other. The vessel was first kept for five minutes at $40^{\circ} \mathrm{C}$, and then the two solutions were mixed. The mixture was incubated at $40^{\circ} \mathrm{C}$ for thirty minutes. At the end of incubation, one $\mathrm{ml}$ of 1.8 per cent trichloroacetic acid was added to the mixture and the resulted precipitate was removed by filtration after standing for thirty minutes at $40^{\circ} \mathrm{C}$. In the control system the reaction mixture was incubated without the enzyme solution which was added immediately after the addition of trichloroacetic acid. The extent of hydrolysis during the incubation period was determined as follows: To one $\mathrm{ml}$ of the filtrate $2.5 \mathrm{ml}$ of $0.55 \mathrm{M}$ sodium bicarbonate was added, followed by $0.5 \mathrm{ml}$ of three fold diluted Folin's reagent $t^{12)}$. After thoroughly mixing of the solution and standing for thirty minutes at $30^{\circ} \mathrm{C}$, the blue color developed was measured by use of an electric photometer (Model 2 of Tōyō Roshi Co., Ltd., Japan) at $660 \mathrm{~m} \mu$.

The enzyme activity is expressed in units, one unit being defined as the amount of enzyme that liberates TCA soluble hydrolyzate corresponding to one $\mu$ mole as tyrosine per minute under the condition. Specific activity was expressed in units per $\mathrm{mg}$ of protein $\mathrm{N}$ of the enzyme; the total activity in units of an enzyme solution was calculated from the specific activity multiplied by $\mathrm{mg}$ of protein $\mathrm{N}$ in the enzyme solution.

\section{Protein Determination.}

The amount of protein was determined by either the micro-Kjeldahl method or Lowry's method ${ }^{13)}$.

\section{RESULTS AND DISCUSSION}

Among 8 strains of Streptomyces* which

10) M.L. Anson, J. Gen. Physiol., 22, 79 (1938).

11) S. Akabori, "Mcthod in Enzymology", (in Japanese) II, Asakura press, 1957, p. 242.

12) O. Folin and V. Ciocalteu, J. Biol. Chem., 73, 627 (1927).

13) O.H. Lowry, N.J. Rosenbrough, A.L. Forr and R.T. Randall, J. Biol. Chem., 193, 265 (1951).

* Other strains tested are as follows: Streptomyces antibioticts NRRI B 546, Streptomyces reticuli IFO 3354, Streptomyces griseolus ATCC 11796 and Streptomyces retgersensis WK 3350. seem to have a comparatively strong proteolytic enzyme, 4 strains such as Streptomyces lavendulae ATCG 8664, Streptomyces griseus ATCC 3463, Streptomyces griseus ATCC 10137 and Streptomyces griseus X-28 showed strong activities of peptidase and proteinase.

Of these 4 Streptomyces strains, Streptomyces griseus ATCC 3463 had the most potent peptidase- and proteinase activity. As for the action of peptidase of the fungus, the filtrate of the cultural media showed a strong hydrolytic action on leucyl peptide such as LeuGly-Gly, Leu-Gly and Leu-NH . But it does not act on Gly-Gly and Gly-Gly-Leu. In addition to the peptidase activity mentioned above, the filtrate also showed a strong proteolytic action for casein. From the culture filtrate of this fungus, peptidase was fractionally precipitated at 66 to 80 per cent ethanol concentration followed by salting out at 0.5 to 0.7 saturation with ammonium sulfate at pH 7.0, but proteinase was precipitated between 50 and 66 per cent ethanol concentration and salted out with ammonium sulfate from 0.3 to 0.5 saturation at $\mathrm{pH}$ 7.0. Each concentrated enzyme was then dialyzed and subjected to zone electrophoresis on potato starch. Application of this process presented here enabled the author to separate and purify the two enzymes from the culture filtrate of the fungus (Table I, Fig. 1 and 3). Fig. 2 shows a migration pattern of peptidase activity in the second run, indicating that the enzyme is electrophoretically a single enzyme protein. It was indicated that the activity was in accordance with the protein peak. Fig. 4 shows the time course of the peptidase reaction. By this procedure, the peptidase was isolated in a state completely free of proteinase. The proteinase was also purified without any contamination of peptidase (Fig. 3) . Good reproducibility was obtained by the method mentioned above in the purification 
TABLE I. PROCEDURES FOR PURIFICATION OF PROTEINASE AND PEPTIDASE

Step

Crude solution

Ethanol

precipitation

1st ammonium sulfate

precipitation

1st dialysis at

2nd ammonium sulfate

precipitation

2nd dialysis at

Heating

1st electrophoretic

separation*

2nd electrophoretic

separation*
Proteinase Peptidase

Concentrated Concentrated to $1 / 2$ vol. to $1 / 2 \mathrm{vol}$.

$\begin{array}{cc}50 \sim 66 \% & 66 \sim 80 \% \\ 0.3 \sim 0.5 & 0.4 \sim 0.8 \\ \text { saturation } & \text { saturation } \\ \mathrm{pH} 8.0 & \mathrm{pH} 8.0 \\ - & 0.5 \sim 0.7 \\ - & \text { saturation } \\ - & \mathrm{pH} 8.0 \\ - & 60^{\circ} \mathrm{C}, 20 \mathrm{~min} . \\ 10 \mathrm{~cm} & 5 \mathrm{~cm} \\ - & 5 \mathrm{~cm}\end{array}$

* Distance of migration toward cathode from point of application on starch block,

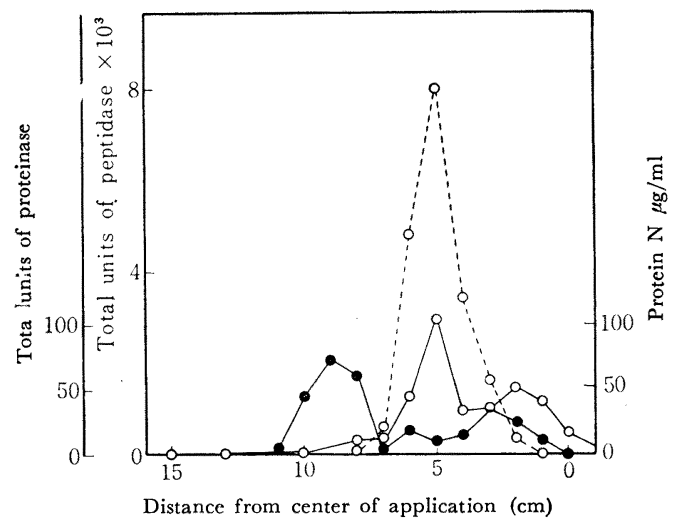

FIG. 1. Distribution of Enzyme Activities and Protein $\mathrm{N}$ along the Starch Zone by the Electrophoretic Run.

The first run was performed at $6^{\circ} \mathrm{C}$ for 15 hours at $14 \mathrm{~m}$ amp and $400 \mathrm{~V}$. The buffer used was $0.06 \mathrm{M}$ veronal $\mathrm{pH} 8.6$. The enzyme moved toward the cathode. After the run, the starch block was cut into $1-\mathrm{cm}$-length and eluted with $5 \mathrm{ml}$ of water, the eluate were assayed for protein $\mathrm{N}$ and the proteolytic enzyme activity.

$$
\begin{array}{ll}
--0-- & \text { Peptidase } \\
-\mathrm{O}- & \text { Proteinase } \\
- & \text { Protein N }
\end{array}
$$

and separation of both peptidase and proteinase. The change in activity during purification of peptidase and proteinase are shown in Table iI and III, respectively. The purity of peptidas: was found to increase to about 90 fold, and proteinase approximately to 8 times.

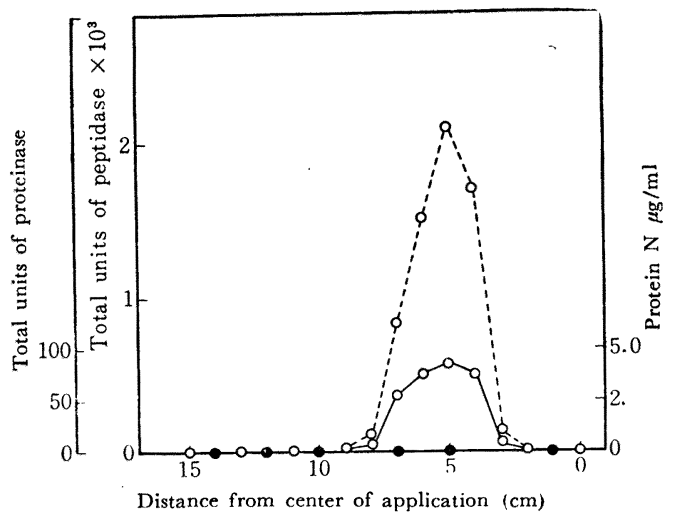

FIG. 2. Separation of Peptidase by the Zone Electrophoresis on Potato Starch.

The second run was performed at $6^{\circ} \mathrm{C}$ for 19 hours at $14 \mathrm{~m}$ amp and $320 \mathrm{~V}$. The buffer used was $0.06 \mathrm{~m}$ veronal $\mathrm{pH}$ 8.6. The enzyme moved toward the cathode. The assay method of the proteolytic enzyme was the same as those in Fig. 1.
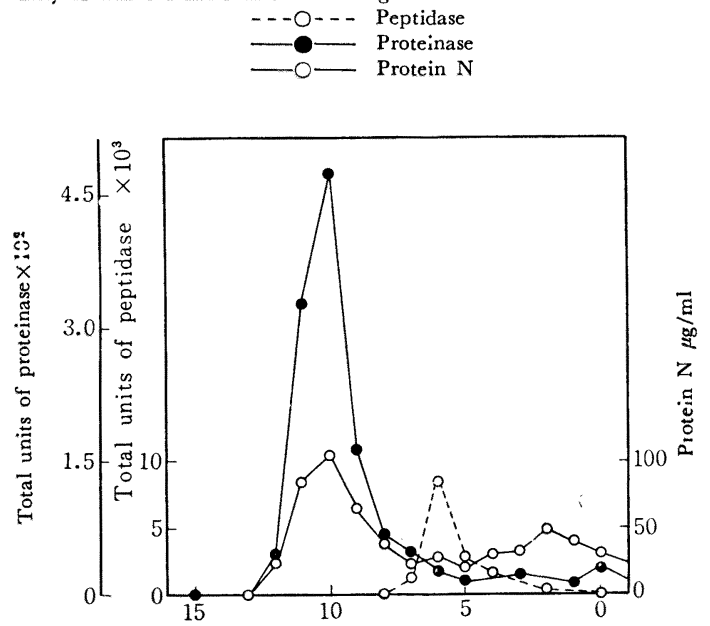

Distance from center of application $(\mathrm{cm})$

FIG. 3. Movement of Proteins and Proteinase by the Zone Electrophoresis on Potato Starch.

The run was performed at $6^{\circ} \mathrm{C}$ for 20 hours at $7.5 \mathrm{~m}$ amp and $210 \mathrm{~V}$. The buffer used was $0.06 \mathrm{~m}$ veronal $\mathrm{pH}$ 8.6. The enzyme moved toward the cathode. The assay method of the proteolytic enzyme was the same as those in Fig. 1.

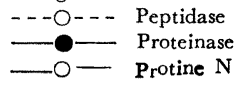

In an experiment with a strain of Streptomyces griseus applying the column chromatography with Kaken C-1, Nomoto and his coworkers $^{1,2)}$ succeeded in the purification to obtain a single component protease which 
hydrolyzed various substrates for both endo-

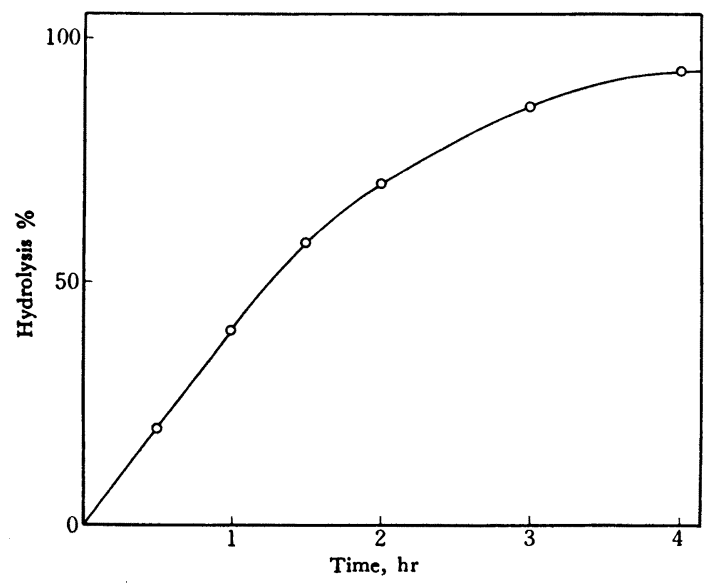

FIG. 4. The Hydrolysis of Leu-Gly by Peptidase.

The reaction mixture contained $0.5 \mathrm{ml}$ of substrate buffer solution $(0.20 \mathrm{M}$ Leu-Gly in $0.10 \mathrm{M}$ tris, $\mathrm{pH} 8.0 ;, 0.1 \mathrm{ml}$ of enzyme solution $(0.2 \mu \mathrm{g}$ of protein $\mathrm{N}$ per $\mathrm{ml})$ and water in a total volume of $1.0 \mathrm{ml}$. Incubated at $40^{\circ} \mathrm{C}$. At intervals, $0.2 \mathrm{ml}$ aliquots were withdrawn, and titrated with $1 / 100 \mathrm{~N} \mathrm{KOH}$ ethanol solution.

TABle II. PURIfication OF PePtidase From CULTURE Filtrate

Fraction

Total

Crude solution protein Total Specific $\mathrm{N}$ mg units activity

Ethanol precipitation 160

$162880 \quad 1018$

1st ammonium sulfate

$95.2 \quad 109480 \quad 1150$

precipitation

$\begin{array}{lll}41.7 & 51000 \quad 1223\end{array}$

2nd ammonium sulfate precipitation

$\begin{array}{lll}7.7 & 49800 \quad 6468\end{array}$

Heating

1st electrophoretic

separation

$6.6 \quad 53230 \quad 8065$

$0.43 \quad 19435 \quad 48585$

2nd electrophoretic separation

(46)*

453598590

* $\mu \mathrm{g}$.

This is a typical run for $2000 \mathrm{ml}$ of culture media.

TABle III. PuRIfication OF PROTEINASE FORM Gulture Filtrate

\begin{tabular}{lcrc}
\multicolumn{1}{c}{ Fraction } & $\begin{array}{c}\text { Total } \\
\text { protein } \\
\text { N mg }\end{array}$ & $\begin{array}{r}\text { Total } \\
\text { units }\end{array}$ & $\begin{array}{c}\text { Specific } \\
\text { activity }\end{array}$ \\
$\begin{array}{l}\text { Grude solution } \\
\begin{array}{l}\text { Ethanol } \\
\text { precipitation }\end{array}\end{array}$ & 30.6 & 5416 & 177 \\
$\begin{array}{l}\text { Ammonium sulfate } \\
\text { precipitation }\end{array}$ & 5.1 & 2478 & 486 \\
$\begin{array}{l}\text { Electrophoretic } \\
\text { separation }\end{array}$ & 0.3 & 263 & 876 \\
\hline
\end{tabular}

This is a typical run for $2000 \mathrm{ml}$ of culture media. peptidase and exopeptidase assay. The proteolytic enzyme of Streptomyces griseus ATCC 3463 is quite different from the protease of Streptomyces griseus studied by Nomoto and his coworkers. The results described here show that the proteolytic enzyme of Streptomyces griseus ATCC 3463 consists of, at least, two kinds of enzymes, namely peptidase and proteinase. Further studies on properties of the both enzyme will be presented elsewhere and discussed.

\section{SUMMARY}

1. A method for isolating peptidase and proteinase from culture media of Streptomyces griseus was described.

2. It was shown that in the culture media of Streptomyces griseus ATCC 3463, peptidase and proteinase were present and the two enzymes were obtained in a highly purified state, respectively.

Acknowledgement. The author wishes to express his sincere thanks to Prof. M. Sato of Ibaraki University, for his kind guidance and encouragement throughout the course of this study, and also to Prof. Y. Nakamura and Y. Obata of Hokkaido University, for their encouragement and suggestion. Hearty thanks are due to Prof. H. Ariyama of Tōhoku University, for his kind advice and encouragement throughout the course of this study and to Prof. S. Funahashi of the University of Tokyo, for his kind permission to use the electrophoretic apparatus and the refrigerated centrifuge. $\mathrm{He}$ is also indebted to Mr. A. Hiramatsu of this laboratory, for his kind cooperation in carrying out this work. Several Streptomyces strains were generously supplied through the courtesy of Dr. S. Umesawa of the National Institute of Health and also Mr. N. Arishima of the Institute of Meiji Seika Co., Ltd. This work was supported in part by a grant in aid of scientific research from the Ministry of Education. 